\title{
Combined analyses of the size spectra and biochemical composition of particles in the St. Lawrence estuary*
}

\author{
Poulet, S. A. ${ }^{* *}$, D. Cossa ${ }^{* *} \&$ J.-C. Marty ${ }^{* * * *}$ \\ Laboratoire Océanographique de Rimouski, 310 avenue des Ursulines, Rimouski, Québec G5L 3A1, Canada
}

\begin{abstract}
A study of the size, concentration and biochemical composition of particles originating from surface waters of the lower St. Lawrence estuary was carried out using principal component and discriminant analyses. This approach emphasizes multivariate analyses as tools to achieve combined descriptions of the size distribution and of the chemical composition of particles. The principal component analysis allowed the identification of 4 groups of spectra on the basis of particle sizes and concentrations. Identification of the biochemical characteristics of each group was based on carbon, nitrogen, proteins, carbohydrates, lipids, chlorophyll a and adenosine triphosphate and silica fraction. The discriminant analysis allowed ranking of 7 variables combined in 2 discriminant functions, which furthermore allowed grouping of particle spectra according to their biochemical characteristics. Results show that particles in the St. Lawrence estuary had distinct chemical characteristics varying with the categories of spectra, the size fractions and the biogenic or terrigeneous origin of the particles. The nutritive value of particles changed with the group of spectra and according to the size fractions. Particles having combined concentrations of proteins, carbohydrates and lipids $<10 \%$ of particulate organic matter (POM) were assumed to have the lowest nutritive value. This coincided with $\mathrm{C} / \mathrm{N}$ ratios $>17$. Higher percentages relative to POM $(17$ to $34 \%)$ were measured in particles whose $\mathrm{C} / \mathrm{N}$ ratios varied from 6 to 17 . These particles were assumed to have the highest food value. Below and above the $15 \mu \mathrm{m}$ size threshold, the nutritive value of the particulate matter, relative to POM, was not related to the concentration of ATP, used as an index of living particles, because these particles had a minor influence on the biochemical composition of the seston, compared to the dominant non-living fraction. Depending on the size fraction, detritus had nutritive value similar to the living matter.
\end{abstract}

\section{INTRODUCTION}

While a great deal of data concerning the size and concentration of particles in various marine, coastal and estuarine regions are now available (e.g. Postma 1967. Riley 1970, Schubel 1971, Sheldon et al. 1972, Cauwet 1978), the biological importance of suspended particulate matter (SPM) has received little attention (Parsons 1969, Riley 1970, Sheldon et al. 1972, Valkenberg et al. 1978, Malone \& Chervin 1979, Chervin et al.

- Contribution of INRS-Océanologie (Université du Québec)

Present addresses:

- Station biologique, CNRS, F-29211, Roscoff, France

-.. IFREMER, Centre de Nantes, BP 1049, 44037 Nantes Cédex, France

... Laboratoire de Physique et Chimie marines, Université P. et M. Curie, 4, Place Jussieu, F-75005 Paris, France
1981, Mayzaud et al. 1984). To define the rôle of particles in various biological processes both size and biochemical composition must be considered together. The majority of chemical studies have determined particulate organic carbon (POC) and nitrogen (PON), e.g. Riley 1970, Cauwet 1978, Gordon et al. 1979. The definition of particles in terms of SPM, POC or PON alone is not sufficient, and other biochemical variables relevant to marine food webs should be investigated (Poulet 1983). Natural diets of filter-feeders consist of assemblages of mixed particles having different nutritive values according to their biochemical composition (Jørgensen 1966, Conover 1978, Mayzaud et al. 1984). For example, among calanoid copepods, the biochemical composition of particulate food controls the ingestion, rejection and assimilation processes (Boucher et al. 1975, Conover 1978, Mayzaud \& Poulet 1978, Chervin et al. 1981, Huntley 1982, Baars \& Oosterhuis 1984, 
Roman 1984, Poulet et al. 1985); and thus, obtaining information on the biochemical composition of naturally occurring particles is relevant to a better understanding of the biological influence of SPM.

This study investigates the relation between the size spectrum and the biochemical composition of SPM measured in an estuarine environment, where the variability of particles, in time and space, is great and depends on both physical and biological factors (Chanut \& Poulet 1982).
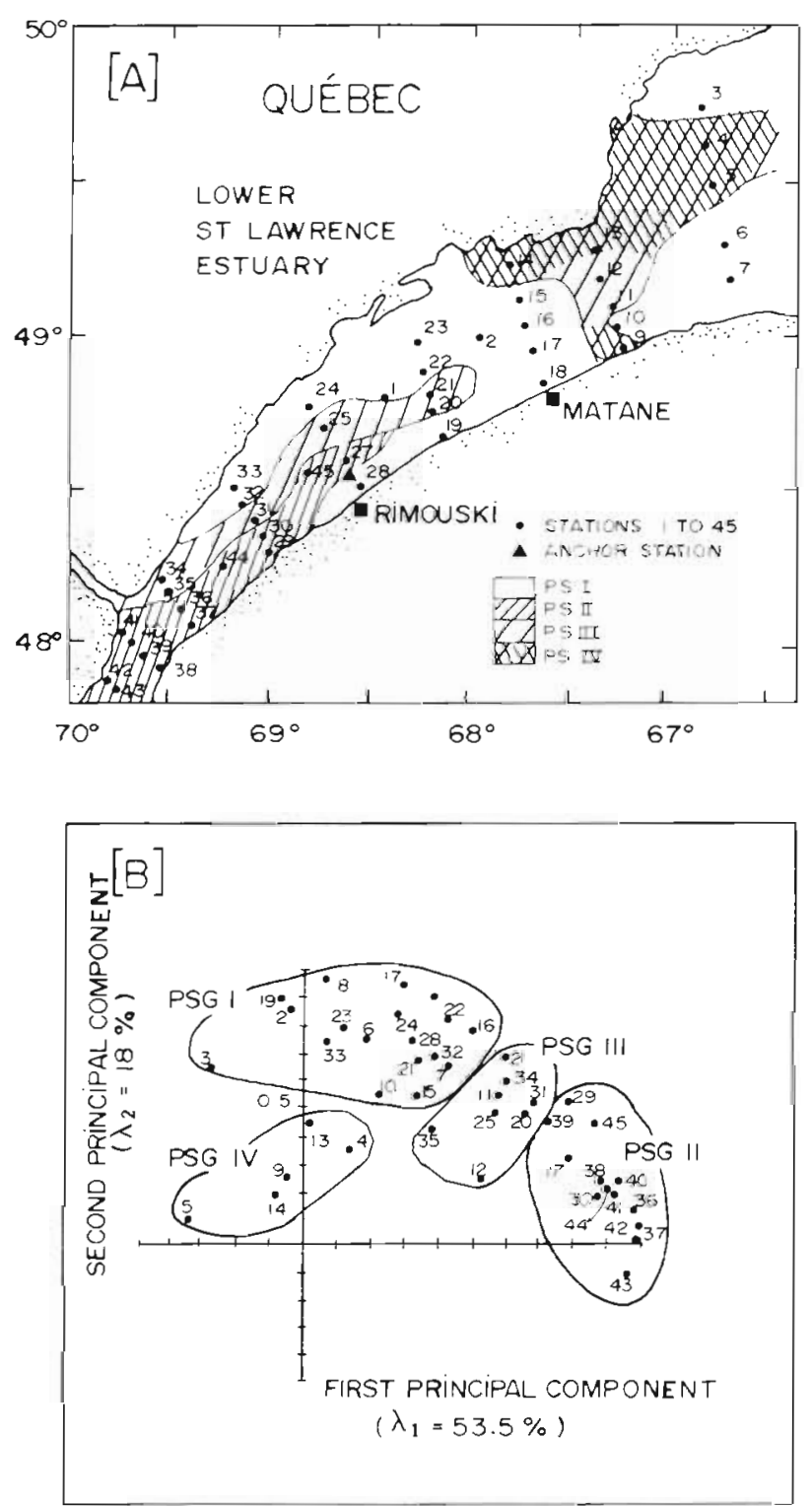

Fig. 1. Particles in the surface waters of the lower St. Lawrence estuary, Canada. (A) Positions of the stations and spatial distribution of the groups of spectra (PSG I to IV) defined by principal component analysis. (B) PCA. Boundaries between groups have been defined on the basis of visual examination and Kolmogorov-Smimov tests (Table 1); data points correspond to station numbers

\section{METHODS}

Seawater was sampled in the lower St. Lawrence estuary on 2 occasions during 1975: (1) at 45 stations, $5 \mathrm{~m}$ depth, over $5 \mathrm{~d}$ (July 17 to 21 ) and (2) at one anchor station, $5 \mathrm{~m}$ depth, every $2 \mathrm{~h}$, over $3 \mathrm{~d}$ (July 31 to August 4) (Fig, 1A). The concentration (particle volume) and size distribution (in the 1 to $150 \mu \mathrm{m}$ range $; 25$ size classes measured) of SPM were measured in duplicate with a Coulter counter (Model TA) using a $50 \mu \mathrm{m}$ and $280 \mu \mathrm{m}$ aperture tube, according to Sheldon \& Parsons (1967). Chemical analyses of the SPM were made only once for each compound measured in the seston $(<202 \mu \mathrm{m})$ and in the nanoplankton $(<15 \mu \mathrm{m})$. The concentrations of the compounds in the 15 to $202 \mu \mathrm{m}$ fraction were obtained from the difference between the 2 former categories. Samples for the seston and nanoplankton fractions were sieved respectively on $202 \mu \mathrm{m}$ and $15 \mu \mathrm{m}$ Nitex screens. All samples were collected at the same time and filtered on glassfiber filters (Gelman, GA, pre-ashed at $500^{\circ} \mathrm{C}$ for $12 \mathrm{~h}$ ), except samples for chlorophyll a, ATP and silica fraction (SF) which were filtered on cellulose acetate membrane (Millipore, HAO, $0.8 \mu \mathrm{m}$ ). Classical methods were used to analyse particulate carbon (POC) and nitrogen (PON), chlorophyll a (CHL), adenosine triphosphate (ATP), total proteins (P), total carbohydrates (G) and total lipids (L) (Lowry et al. 1951, Bligh \& Dyer 1956, Dubois et al. 1956, Holm-Hansen \& Booth 1966, Strickland \& Parsons 1967). The weight of the insoluble residue of a nitric acid digestion of the particles gave an evaluation of the SF of the SPM.

While principal component analysis (PCA) was performed to distinguish the different groups of particle spectra (PSG) versus space and time, as shown by Chanut \& Poulet (1982), the discrimination of the spectra on the basis of their chemical composition was achieved through discriminant analysis (DA) (Lachenbruch 1977). The SPSS package was used for both muitivariate analyses (Klecka 1975, Nie et al. 1975).

\section{RESULTS AND DISCUSSION}

\section{Particle size spectra grouping}

A PCA of the complete data set ( $\mathrm{n}=90$ samples) shows that the size spectra can be split into 4 major groups (PSG I, II, III, and IV) as illustrated in Fig. 1A, B for the entire lower Estuary and in Fig. 2 for the anchor station. Each group is defined by the coefficient of correlation of the spectra having a similar shape, associated with the principal components as discussed by Chanut \& Poulet (1982). Four couples of characteristic spectra have been selected among the whole data 


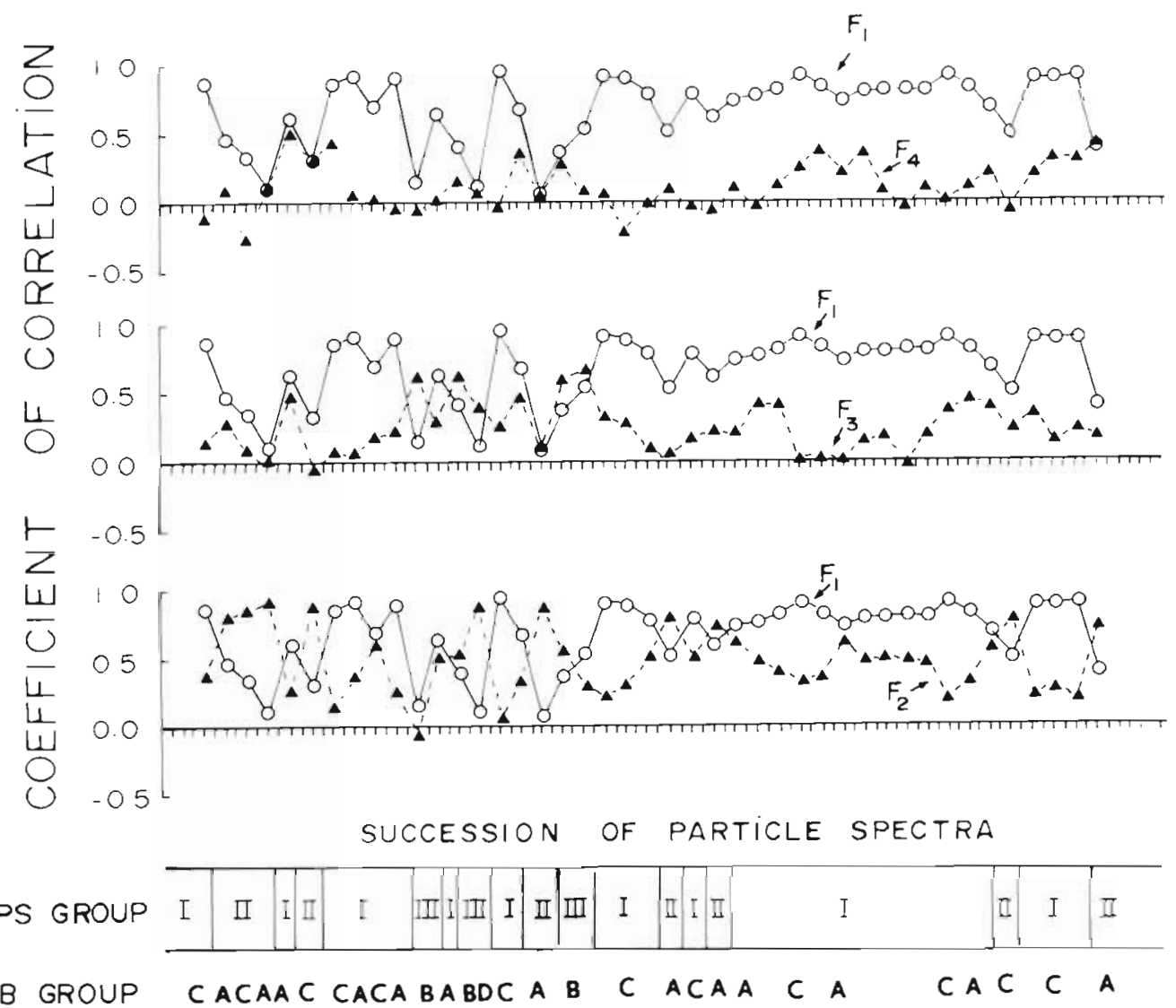

SUB GROUP CACAAC CACABABDCAB C ACAA C A CAC C A

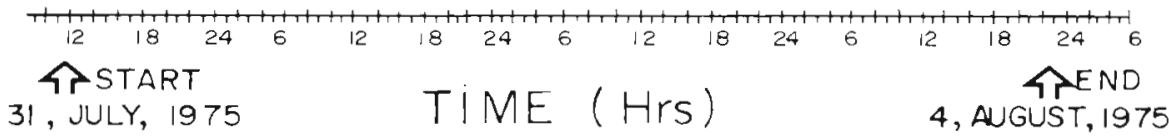

Fig. 2. Short-term sequences of particle spectra on the anchor station, lower St. Lawrence estuary. Values of the coefficients of correlation for the spectra associated with the principal components $F_{1}$ to $F_{4}$ (see Chanut \& Poulet 1982, for details), are used to plot time-series of spectra belonging to PSG I to III and to sub-groups A, B, C, D. (See Poulet et al. 1986, for definition)

set in order to define the groups and to show the upper and lower ranges of variation observed in each group (Fig. 3). The shape of the 4 groups was typically polymodal and can be defined as follows (Fig. 3): PSG I was mainly composed of 'small' $(\sim 5 \mu \mathrm{m})$ and 'large' $(\sim 40 \mu \mathrm{m})$ particles; PSG II was characterized by the dominance of particles $<10 \mu \mathrm{m}$; PSG III was formed mainly of 'medium' size particles ( 8 to $40 \mu \mathrm{m}$ ); in PSG IV particle concentration was highest in the size range $>30 \mu \mathrm{m}$. The groups of particle spectra in Fig. 3 correspond to sub-groups $4 \mathrm{~A}, \mathrm{~B}, \mathrm{C}, \mathrm{D}$ and $5 \mathrm{~A}, \mathrm{~B}, \mathrm{C}, \mathrm{D}$, given by Poulet et al. (1986) for the entire estuary and gulf of St. Lawrence.

The adequacy of the grouping of spectra (PSGs I, II, III and IV) with $\Sigma_{1}^{4} \lambda_{1}=85 \%$ of the total variance was verified by visual examination and by using the Kolmogorov-Smirnov test (Conover 1980) for the entire set of the characteristic spectra. Results in Table 1 indicate that the spectra were not significantly different $(p>0.05)$ when the particle concentration had a small amplitude of variation; however, spectra were significantly different $(p<0.05)$ when the amplitude of variation of the particle concentration was high, leading to drastic changes in the size spectrum (Table 1 and Fig. 3). Results also indicate that the particle spectra in the Estuary presented a continuum in shape, ranging from PSG II to PSG IV (Fig. 1A, B) (Poulet et al. 1986). PSG II corresponded to the plume of particles originating from the upper St. Lawrence estuary, while PSG III was an intermediate group between PSGs I and II which characterize the diffusion zone of the plume (Fig. 1A). Particles in PSGs I and IV were associated with the maritime section of the Estuary (Poulet et al. 1986). In July-August, the ranges of the values, for salinity and temperature, measured in the estuarine waters were 20 to $28 \%$ and 5 to $12{ }^{\circ} \mathrm{C}$ in the case of PSG II; they were 25 to $30 \%$ and 8 to $15^{\circ} \mathrm{C}$ in the case of PSGs I and IV, whereas waters containing PSG III 


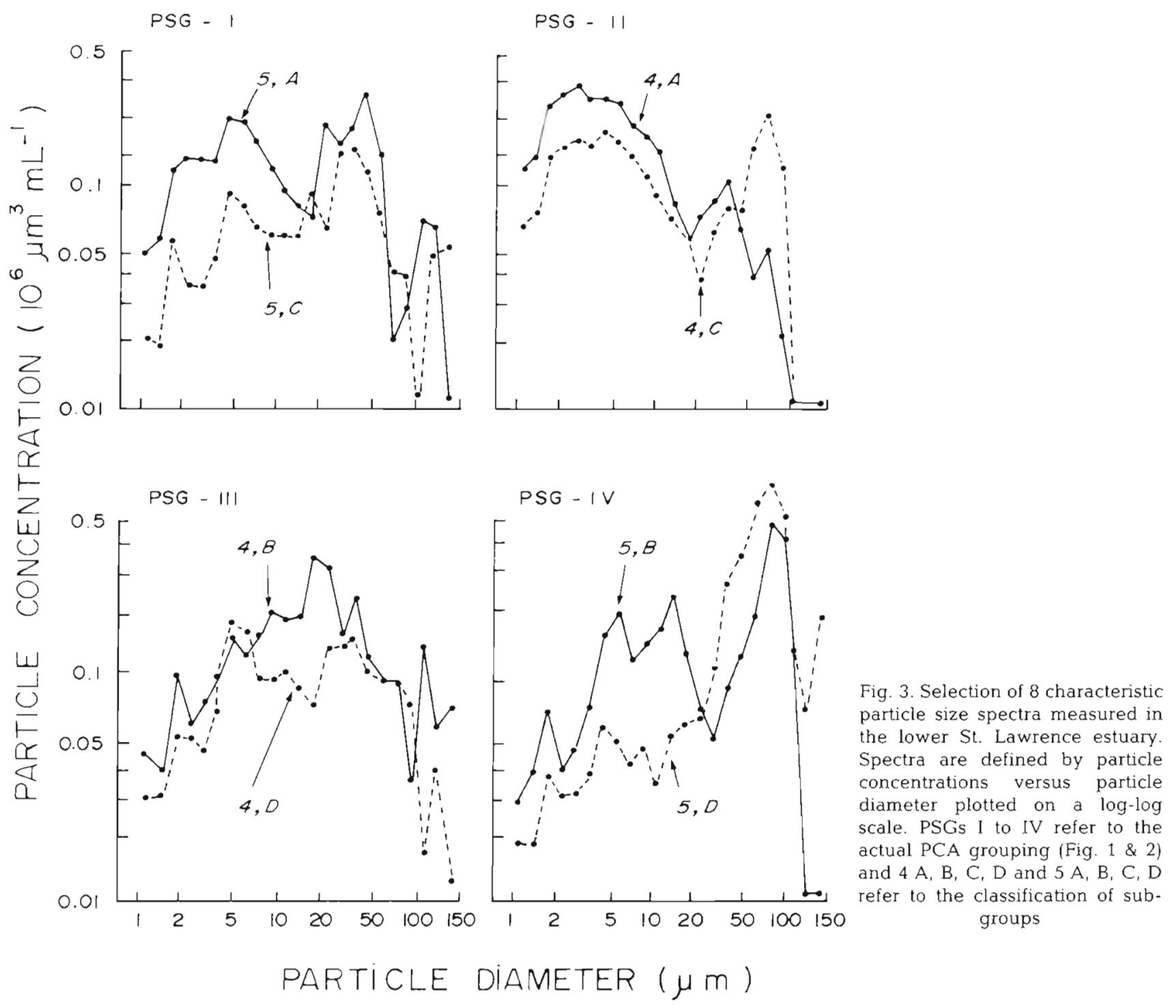

had salinity-temperature patterns intermediate or similar to the others.

The position of the anchor station, located near the boundary (Fig. 1A) between water masses containing PSGs I, II and III, allowed observation of the sequence with time of the spectra (Fig. 2) as a result of the physical instability of this environment (Sinclair et al. 1980, Chanut \& Poulet 1982). In addition, short term variations in groups and sub-groups of spectra (Fig. 2 , bottom: A, B, C and D) contrast with the broad scale distribution of the spectra observed within the Estuary. This succession of sub-groups can be interpreted as patches with dimensions falling between 1 to $40 \mathrm{~km}$, knowing the sequence in time of each group and the range of the current velocity (25 to $90 \mathrm{~cm} \mathrm{~s}^{-1}$ ). The succession in time between the main groups was, in fact, due to the oscillations of the boundary (Fig. 1A) in relation to the variations in direction and speed of the tidal current (Sinclair et al. 1980). The sequences between the sub-groups A, B, C or D (Fig. 2 bottom) corresponded to successions of patches having identical dimensions to those computed for particles and phytoplankton in the same region by Chanut \& Poulet (1982) and by Levasseur et al. (1983).

\section{Discrimination by biochemical composition}

The multivariate approach given by the discriminant analysis (DA) distinguishes the spectra on the basis of their chemical composition (Table 2; Fig. 4). The objective of this approach is to weight and linearly combine the discriminating variables (chemical parameters) so that the groups of spectra are forced to be statistically distinct (Klecka 1975). Three discriminant analyses were performed on 3 matrices formed of 7 
Table 1. Differences in particle spectra. Kolmogorov-Smirnov's test performed on couple of spectra belonging to similar or different groups of spectra (PSG) illustrated in Fig. 3 and discriminated by the PCA (e.g. Fig. 1B). $D_{\text {max }}=\max \left|F_{n_{1}}(X)-F n_{2}(X)\right|$; where $\mathrm{n}=$ number of data points $(\mathrm{n}=25) ; 1$ and $2=$ the 2 samples to be compared; $\mathrm{X}=$ the rank of the size class; $F=$ the cumulative frequency. Critical values for $n=25$ are $\left({ }^{\circ}\right) \mathrm{D}(\mathrm{n} ; \alpha)=0.27$ at $\alpha=0.05$ and (" $\left.\mathrm{C}\right) \mathrm{D}(\mathrm{n} ; \alpha)=0.32$ at $\alpha=0.01$

\begin{tabular}{|c|c|c|c|c|c|}
\hline \multicolumn{3}{|c|}{ Group of spectra } & \multicolumn{3}{|c|}{ Group of spectra } \\
\hline PSG & Subgroup & $\left|D_{\max }\right|$ & PSG & Subgroup & $\left|\mathrm{D}_{\max }\right|$ \\
\hline $\mathrm{I} / \mathrm{I}$ & $5 \mathrm{~A} / 5 \mathrm{C}$ & $0.47 \cdots$ & $\mathrm{II} / \mathrm{II}$ & $4 \mathrm{~A} / 4 \mathrm{C}$ & 0.26 \\
\hline I/II & $5 \mathrm{~A} / 4 \mathrm{~A}$ & 0.13 & Il/III & $4 \mathrm{~A} / 4 \mathrm{~B}$ & $0.48^{*}$ \\
\hline I/II & $5 \mathrm{~A} / 4 \mathrm{C}$ & $0.27^{\circ}$ & Il/III & $4 \mathrm{~A} / 4 \mathrm{D}$ & $0.39^{*}$ \\
\hline I/II & $5 \mathrm{C} / 4 \mathrm{~A}$ & $0.52 \cdots$ & IIIIII & $4 \mathrm{C} / 4 \mathrm{~B}$ & $0.30^{\circ}$ \\
\hline I/II & $5 \mathrm{C} / 4 \mathrm{C}$ & $0.34^{\cdots}$ & $\mathrm{II} / \mathrm{III}$ & $4 \mathrm{C} / 4 \mathrm{D}$ & 0.13 \\
\hline $\mathrm{I} / \mathrm{III}$ & $5 \mathrm{~A} / 4 \mathrm{~B}$ & 0.08 & $\mathrm{II} / \mathrm{IV}$ & $4 \mathrm{~A} / 5 \mathrm{~B}$ & 0.08 \\
\hline $\mathrm{I} / \mathrm{III}$ & $5 \mathrm{~A} / 4 \mathrm{D}$ & 0.08 & II/IV & $4 \mathrm{~A} / 5 \mathrm{D}$ & $0.56^{*}$ \\
\hline I/III & $5 \mathrm{C} / 4 \mathrm{~B}$ & $0.27^{\circ}$ & $\mathrm{II} / \mathrm{IV}$ & $4 \mathrm{C} / 5 \mathrm{~B}$ & 0.04 \\
\hline I/III & $5 \mathrm{C} / 4 \mathrm{D}$ & $0.36^{\cdots}$ & $\mathrm{II} / \mathrm{IV}$ & $4 \mathrm{C} / 5 \mathrm{D}$ & $0.43^{\circ}$ \\
\hline $\mathrm{I} / \mathrm{IV}$ & $5 \mathrm{~A} / 5 \mathrm{~B}$ & $0.27^{\circ}$ & $\mathrm{III} / \mathrm{III}$ & $4 \mathrm{~B} / 4 \mathrm{D}$ & 0.22 \\
\hline I/IV & $5 \mathrm{~A} / 5 \mathrm{D}$ & $0.52 \cdots$ & III/IV & $4 \mathrm{~B} / 5 \mathrm{~B}$ & $0.56^{\cdots}$ \\
\hline I/IV & $5 \mathrm{C} / 5 \mathrm{~B}$ & $0.43 \cdots$ & III/IV & $4 \mathrm{~B} / 5 \mathrm{D}$ & $0.39^{\circ}$ \\
\hline \multirow[t]{3}{*}{$\mathrm{I} / \mathrm{IV}$} & $5 \mathrm{C} / 5 \mathrm{D}$ & 0.17 & $\mathrm{III} / \mathrm{IV}$ & $4 \mathrm{D} / 5 \mathrm{~B}$ & $0.27^{\circ}$ \\
\hline & & & III/IV & $4 \mathrm{D} / 5 \mathrm{D}$ & $0.48 \cdots$ \\
\hline & & & IV/IV & $5 \mathrm{~B} / 5 \mathrm{D}$ & $0.52 \cdots$ \\
\hline
\end{tabular}

discriminant variables by $n=75, n=52$ and $n=36$ samples, respectively, each corresponding to the set of data measured in the size fractions 1 to $202 \mu \mathrm{m}$; $<15 \mu \mathrm{m}$ and $>15 \mu \mathrm{m}$ (Table 3). The discriminant analysis forms one or more linear combinations of the discriminant variables, called discriminant functions $D_{1}$ (Klecka 1975), of the form:

$$
D_{1}=d_{i, 1} Z_{1}+d_{1,2} Z_{2}+\ldots \ldots+d_{i, 7} Z_{7}
$$

where $D_{i}=$ the score on discriminant function $i_{i} d_{i}=$ the weighting coefficients; $Z_{i}=$ the standardized values of the discriminant variables used in the analysis. We only used first and second discriminant functions $\left(D_{1}\right.$ and $\left.D_{2}\right)$ which both have significant Wilks' Lambda and Chi-square $(p<0.05$ ) (Table 2). The larger Wilks' Lambda is, the less discriminating power is present and the Chi-square tells us that a significant difference exists (Klecka 1975, Lachenbruch 1977). The $D_{2}$ func-

NET SESTON $(1-202 \mu \mathrm{m})$

SMALL PARTICLES $(1-15 \mu \mathrm{m})$

LARGE PARTICLES $(15-202 \mu \mathrm{m})$
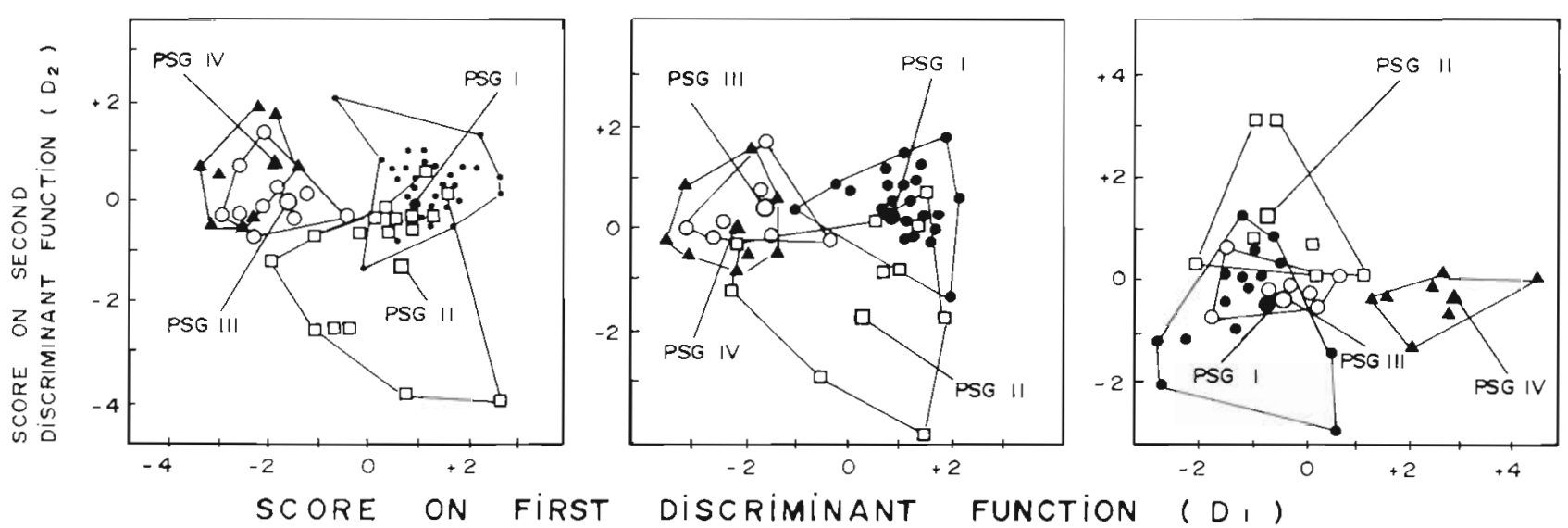

Fig. 4. Discriminant analyses of particle spectra versus chemical composition of SPM performed on 3 particle size fractions. (See

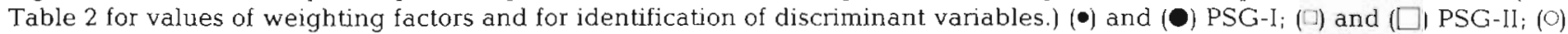
and (O) PSG-III; ( 1 ) and ( $\Lambda$ ) PSG-IV. Small symbols: data points (spectra); large symbols: centroids (PSG) related to each group of particle spectra. Scores of centroids relative to $D_{1}$ and $D_{2}$ : for net seston, PSG I: $(1.30 ; 0.42)$; PSG II: $(0.21 ;-1.07)$; PSG III: $(-2.04$; 0.14); PSG IV: $(-2.06 ; 0.42)$; for small particles, PSG I: $(1.15 ; 0.46)$; PSG II: $(0.38 ;-1.35)$; PSG III: $(-1.82$; 0.27$)$; PSG IV: $(-1.92$, $0.18)$; for large particles, PSG I: $(-0.86 ;-0.42)$; PSG II: $(-0.27 ; 1.24)$; PSG III: $(-0.30 ; 0.09)$; PSG IV $\cdot(2.50 ;-0.20)$ 
Table 2. Chemical characteruzation of SPM in the lower St Lawrence estuary: results of discriminant analyses performed in 3 size fractions. Values of the weighting coefficient $\left(d_{1}\right)$ and rank of the variables $\left(Z_{1}\right)$. CONCP: concentration of SPM; POC: particulate organic carbon; PON: particulate nitrogen; G: carbohydrates; P: proteins; ATP: adenosine triphosphate; SF: silica fraction, computed in the first $\left(D_{1}\right)$ and second $\left(D_{2}\right)$ discriminant functions. $N=$ number of samples; $W L=W i l k s$ Lambda; $\mathrm{Chi}^{2}=$ Chi-square; $\mathrm{df}=$ degree of freedom; $\mathrm{p}=$ probability

\begin{tabular}{|c|c|c|c|}
\hline \multicolumn{2}{|c|}{$\mathrm{D}_{1}$} & \multicolumn{2}{|c|}{$\mathrm{D}_{2}$} \\
\hline \multicolumn{4}{|c|}{ Seston $(1-202 \mu \mathrm{m})(\mathrm{N}=75)$} \\
\hline $\mathrm{POC}$ & +1.22 & CONCP & +0.67 \\
\hline SF & +0.96 & $\mathrm{POC}$ & +0.64 \\
\hline $\mathrm{P}$ & +0.43 & ATP & +0.23 \\
\hline ATP & +0.15 & G & +0.13 \\
\hline G & +0.13 & $P$ & -0.10 \\
\hline PON & -0.44 & PON & -0.44 \\
\hline CONCP & -0.60 & SF & -1.38 \\
\hline \multicolumn{2}{|c|}{$\begin{array}{c}W L=0.19 \\
C h i^{2}=101.3 \\
\mathrm{df}=21 ; p=0.005\end{array}$} & \multicolumn{2}{|c|}{$\begin{array}{c}\mathrm{WL}=0.63 \\
\mathrm{Chi}^{2}=31.3 \\
\mathrm{df}=12 ; \mathrm{p}=0.05\end{array}$} \\
\hline \multicolumn{4}{|c|}{ Small particles $(<15 \mu \mathrm{m})(\mathrm{N}=52)$} \\
\hline POC & +1.37 & ATP & +0.71 \\
\hline SF & +1.04 & POC & +0.44 \\
\hline $\mathrm{P}$ & +0.23 & $\mathrm{P}$ & +0.40 \\
\hline PON & +0.17 & CONCP & +0.27 \\
\hline ATP & +0.11 & PON & +0.16 \\
\hline $\mathrm{G}$ & -0.20 & SF & -0.26 \\
\hline CONCP & -0.40 & G & -1.34 \\
\hline \multicolumn{2}{|c|}{$\begin{array}{c}W L=0.21 \\
C h i^{2}=70.3 \\
\text { df }=21 ; p=0.005\end{array}$} & \multicolumn{2}{|c|}{$\begin{array}{c}W L=0.62 \\
C^{2} i^{2}=20.9 \\
d f=12 ; p=0.05\end{array}$} \\
\hline \multicolumn{4}{|c|}{ Large particles $(>15 \mu \mathrm{m})(\mathrm{N}=36)$} \\
\hline CONCP & +1.34 & $\mathrm{SF}$ & +0.94 \\
\hline $\mathrm{POC}$ & +0.10 & PON & +0.28 \\
\hline P & -0.13 & CONCP & +0.25 \\
\hline $\mathrm{G}$ & -0.20 & ATP & -0.21 \\
\hline PON & -0.27 & $\mathrm{G}$ & -0.25 \\
\hline SF & -0.59 & $\mathrm{POC}$ & -0.41 \\
\hline ATP & -1.03 & $\mathrm{P}$ & -0.80 \\
\hline \multicolumn{2}{|c|}{$\begin{array}{c}W L=0.21 \\
C h i^{2}=45.3 ; \\
d f=21 ; p=0.002\end{array}$} & \multicolumn{2}{|c|}{$\begin{array}{c}W L=0.59 \\
C h i^{2}=15.7 \\
\mathrm{df}=12 ; \mathrm{p}=0.23\end{array}$} \\
\hline
\end{tabular}

tion for particles $>15 \mu \mathrm{m}$ was not significant $(p=0.23)$ (Table 2). Due to incomplete sets of data in the small and large size fractions, values for total lipids and chlorophyll a were not included in the DA, so that the matrices could be homogenized and compatible among all analyses.

The value and sign of $d_{1}$ represent the contribution of each variable $\left(Z_{1}\right)$ to the discriminant functions. High contributions are reflected by high or positive values, whereas low contributions are reflected by low or negative values of $d_{1}$. In Table 2 , the contributions of the variables are ranked and are summarized by the score of each function (Fig. 4). The variable with a strong positive contribution to the first function was POC and SF for seston (1 to $202 \mu \mathrm{m}$ ) and for small particles $<15 \mu \mathrm{m}$, and was total particle concentration CONCP for large particles $>15 \mu \mathrm{m}$ (Table 2). A strong positive contribution in the second function was due to CONCP and POC in seston and to ATP in small particles (Table 2). A negative contribution was found for $\mathrm{SF}$ and $\mathrm{G}$ in the latter categories (Table 2). Generally the contribution of the majority of the biochemical compounds ( $\mathrm{P}, \mathrm{G}, \mathrm{ATP}, \mathrm{PON})$ was low or even negative. Thus, judging from the high and positive contribution of both POC and SF, and the low or negative contribution of ATP, P, G and PON, into the $D_{1}$ function, it is assumed that the first function reflects the detritus fraction of the organic matter. On the other hand, it seems that the $\mathrm{D}_{2}$ function reflects organic and living particles, as suggested by the rank and sign of ATP and POC in net seston and in particles smaller than $15 \mu \mathrm{m}$ (Table 2).

The results of the 3 discriminant analyses (Table 2) are summarized in Fig. 4, where the spectra of PSGs I to IV and the centroid of each group have been identified. Looking at the score of each centroid for seston and for small particles, it appears that $\mathrm{D}_{1}$ discriminates only PSGI and II from PSG III and IV whereas $D_{2}$ discriminates only PSG II from the 3 other PSGs (Fig. 4). For large particles, $D_{1}$ discriminates clearly PSG IV from the 3 other PSGs, while $D_{2}$ is not significant (Table 2; Fig. 4). The rank of the 7 variables (Table 2) and the value and sign of the score of each centroid (Fig. 4) allow summarizing the following patterns: (1) The chemical characteristics established for particles less than $15 \mu \mathrm{m}$ are similar to those in seston (1 to $202 \mu \mathrm{m}$ ), for each group of spectra. (2) The relative contribution of detritus decreases from Groups I to IV. It is the highest in particles belonging to Groups I and II $\left(D_{1}>0\right)$, compared to particles in Groups III and IV $\left(D_{1}<0\right)$. (3) The contribution of living material is similar in Groups I, III, IV $\left(\mathrm{D}_{2}>0\right)$, and is minimum in Group II $\left(D_{2}<0\right)$. (4) For large particles (15 to $\left.202 \mu \mathrm{m}\right)$, the contrbution of detritus is hughest in Group IV $\left(D_{1}>0\right)$, whereas it is much reduced in the other groups $\left(D_{1}<0\right)$. (5) The continuum existing in the chemical characteristics, from one group to the other, can be evaluated simply by looking at the sign of the scores for each spectrum or group of spectra, relative to both $D_{1}$ and $D_{2}$ functions. These properties are relevant to the detailed and complex data listed in Tables 3 and 4 on which they are based. While these results confirm the complexity and heterogeneity of the chemical composition of assemblages of naturally occurring particles, they also clearly demonstrate that the differentiation of the spectra established by the PCA corresponds 
to the discrimination established by the DA (Fig. 1B, 3 \& 4; Tables $1 \& 2$ ). Therefore, the chemical characteristics of the particles are changing according to the size fraction and to the shape of the spectrum.

\section{Chemical composition versus particle size}

Means of the particle concentrations CONCP and of the biochemical compounds measured in SPM are listed in Table 3. CONCP was, on average, similar in all PSGs, but, with the exception of PSGIV, it was more abundant ( 50 to $70 \%$ ) in small particles compared to larger ones (Table 3). For PSG III it was about equal. We are aware that the fractionation of water samples through small mesh screens (15 to $20 \mu \mathrm{m}$ ) creates artefacts when large particles dominate the net plankton (Malone et al. 1979). In our samples, large particles are found mainly in PSG IV and to a less extent in PSG III (Fig. 3, CONCP in Table 3). Although we have not evaluated the artefact due to sieving, we assume that it should be restricted to the results related to PSGs III and IV which formed less than $15 \%$ of the total samples analysed. The concentration of POC in the Estuary was high, with more than $80 \%$ of the total being contained in particles $<15 \mu \mathrm{m}$, as shown earlier for various types of small particles (Mullin 1965 , Strathmann 1967. Hitchock 1982). The concentrations of total proteins, carbohydrates and lipids were low; and all combined they counted for less than $10 \%$ of the POM (POM $=2 \times \mathrm{POC}$ ) measured in the small particle size fraction $(<15 \mu \mathrm{m}$; Table 3$)$. With the exception of PSG IV, higher values were found for large particles $(>15 \mu \mathrm{m})$ in which P. G and L combined represented 17 to $34 \%$ of the POM. Such a low contribution of the combined P, G, L versus POC has been reported also for SPM collected in surface waters (Jullien et al. 1982). Previous reports by Sinclair et al. (1980) show that chlorophyll a is generally below $3 \mu \mathrm{g}^{-1}$ during

Table 3. Means and standard deviations of the variables measured in the seston, small particles and computed for the large particles. CONCP: concentration of SPM $\left(10^{5} \mu \mathrm{m}^{3} \mathrm{ml}^{-1}\right)$; POC: particulate organic carbon ( $\mu$ g $\left.\mathrm{l}^{-1}\right)$; PON: particulate organic nitrogen $\left(\mu \mathrm{g} \mathrm{l}^{-1}\right)$; P: proteins $\left(\mu \mathrm{g} \mathrm{l}^{-1}\right)$; G: carbohydrates $\left(\mu \mathrm{gl}^{-1}\right)$; L: lipids $\left(\mu \mathrm{g} \mathrm{l}^{-1}\right)$; CHL: chlorophyll a ( $\mu \mathrm{g} \mathrm{l^{-1 }}$ ); ATP: adenosine triphosphate (ng l-1); SF: silica fraction ( $\mathrm{mg} \mathrm{l}^{-1}$ ). Number of samples is in brackets

\begin{tabular}{|c|c|c|c|c|c|c|c|c|c|c|c|c|}
\hline Variable & \multicolumn{3}{|c|}{ PSG I } & \multicolumn{3}{|c|}{ PSG II } & \multicolumn{3}{|c|}{ PSG Ill } & \multicolumn{3}{|c|}{ PSG IV } \\
\hline \multicolumn{13}{|c|}{ Seston $(1-202 \mu \mathrm{m})$} \\
\hline CONCP & 2.16 & 0.62 & $(36)$ & 2.27 & 1.02 & $(27)$ & 2.39 & 0.83 & (15) & 2.3 & 0.6 & (12) \\
\hline $\mathrm{POC}$ & 1055 & 99 & (36) & 849 & 154 & (25) & 741 & 125 & (14) & 758.2 & 191 & (12) \\
\hline PON & 38.7 & 15.1 & (36) & 29.3 & 11.5 & (25) & 50.8 & 17.2 & (13) & 43.9 & 18.8 & (12) \\
\hline $\mathrm{P}$ & 58.8 & 37.0 & (34) & 40.1 & 18.4 & (22) & 61.8 & 31.8 & (15) & 49.4 & 16.1 & (12) \\
\hline $\mathrm{G}$ & 36.9 & 23.4 & (36) & 19.7 & 9.2 & (25) & 34.3 & 16.2 & (15) & 22.3 & 13.3 & (12) \\
\hline L & 49.1 & 8.5 & (29) & 47.1 & 9.3 & (25) & 47.6 & 8.9 & (15) & 40.7 & 5.1 & (12) \\
\hline $\mathrm{CHL}$ & 1.37 & 0.64 & (35) & 0.65 & 0.32 & (25) & 1.32 & 0.93 & (15) & 1.02 & 0.47 & (12) \\
\hline ATP & 264 & 109 & (36) & 199 & 190 & (27) & 319 & 172 & (15) & 254 & 179 & (12) \\
\hline $\mathrm{SF}$ & 0.72 & 0.23 & (35) & 0.95 & 0.82 & (24) & 0.32 & 0.24 & (13) & 0.26 & 0.21 & (12) \\
\hline \multicolumn{13}{|c|}{ Small particles $(<15 \mu \mathrm{m})$} \\
\hline CONCP & 1.17 & 0.23 & (36) & 1.58 & 0.83 & $(27)$ & 1.20 & 0.40 & (15) & 1.01 & 0.26 & (12) \\
\hline POC & 992 & 94 & (30) & 810 & 173 & (17) & 636 & 111 & (10) & 615 & 171 & (10) \\
\hline PON & 28.9 & 9.0 & (34) & 24.9 & 11.3 & (21) & 37.3 & 13.5 & (14) & 32.1 & 13.2 & (12) \\
\hline $\mathrm{P}$ & 34.0 & 14.2 & (32) & 30.8 & 12.9 & (18) & 49.4 & 16.4 & (12) & 37.2 & 16.4 & (12) \\
\hline $\mathrm{G}$ & 13.3 & 5.8 & (36) & 12.0 & 5.1 & (25) & 16.9 & 5.9 & (15) & 15.1 & 8.2 & (12) \\
\hline L & 43.5 & 6.0 & (28) & 45.1 & 9.0 & (20) & 42.4 & 8.8 & (14) & 40.6 & 6.2 & (10) \\
\hline $\mathrm{CHL}$ & 0.72 & 0.39 & (35) & 0.36 & 0.15 & (13) & 0.83 & 0.43 & (14) & 0.77 & 0.45 & (11) \\
\hline ATP & 145 & 53 & (36) & 137 & 153 & $(27)$ & 216 & 187 & (15) & 157 & 80 & (12) \\
\hline $\mathrm{SF}$ & 0.56 & 0.18 & (34) & 0.89 & 0.70 & (23) & 0.18 & 0.14 & (12) & 0.21 & 0.18 & (12) \\
\hline \multicolumn{13}{|c|}{ Large particles $(>15 \mu \mathrm{m})$} \\
\hline CONCP & 0.99 & 0.46 & $(36)$ & 0.68 & 0.25 & $(27)$ & 1.19 & 0.48 & (15) & 1.32 & 0.42 & $(12)$ \\
\hline $\mathrm{POC}$ & 89 & 85 & $(26)$ & 77 & 85 & (16) & 108 & 84 & (9) & 172 & 75 & (9) \\
\hline PON & 11.4 & 10.2 & (28) & 6.8 & 5.0 & $(17)$ & 15.6 & 11.1 & (12) & 13.1 & 8.7 & (11) \\
\hline $\mathrm{p}$ & 31.0 & 30.2 & (28) & 13.4 & 11.2 & (18) & 21.8 & 20.3 & (11) & 12.8 & 7.0 & (11) \\
\hline $\mathrm{G}$ & 23.6 & 19.5 & (36) & 7.7 & 5.4 & (25) & 16.7 & 12.7 & (15) & 7.9 & 5.7 & (11) \\
\hline $\mathrm{L}$ & 6.6 & 6.1 & (24) & 6.0 & 5.3 & (12) & 7.7 & 5.1 & (11) & 3.9 & 1.4 & (4) \\
\hline $\mathrm{CHL}$ & 0.64 & 0.60 & (35) & 0.25 & 0.22 & (13) & 0.53 & 0.59 & (14) & 0.31 & 0.09 & (11) \\
\hline ATP & 119 & 76 & (36) & 64 & 68 & (26) & 143 & 105 & (15) & 97 & 130 & (12) \\
\hline $\mathrm{SF}$ & 0.17 & 0.10 & (33) & 0.14 & 0.18 & (20) & 0.09 & 0.04 & (12) & 0.05 & 0.04 & (12) \\
\hline
\end{tabular}


Table 4.Chemical indices relatıve to the origin and potential food value of SPM in each group of spectra (PSG) and in 3 size fractions. POC, SF, PON, P, G, L: as in Tables 2 and 3. w: weight. Ratios are computed from the data in Table 3

\begin{tabular}{|c|c|c|c|c|}
\hline Ratio & PSG I & PSG II & PSG III & PSG IV \\
\hline \multicolumn{5}{|c|}{ Seston $(1-202 \mu \mathrm{m})$} \\
\hline $\mathrm{POC} / \mathrm{SF}\left(\mathrm{w} / \mathrm{w} \times 10^{-3}\right)$ & 1.47 & 0.89 & 2.32 & 2.92 \\
\hline $\mathrm{POC} / \mathrm{PON} ; \mathrm{C} / \mathrm{N}(\mathrm{w} / \mathrm{w})$ & 27.3 & 29.0 & 14.6 & 17.3 \\
\hline $\mathrm{P} / \mathrm{G} / \mathrm{L}(\mathrm{w} / \mathrm{w} / \mathrm{w})$ & $1.2 / 0.8 / 1$ & $0.9 / 0.4 / 1$ & $1.3 / 0.7 / 1$ & $1.2 / 0.6 / 1$ \\
\hline \multicolumn{5}{|c|}{ Small particles $(<15 \mu \mathrm{m})$} \\
\hline $\mathrm{POC} / \mathrm{SF}\left(\mathrm{w} / \mathrm{w} \times 10^{-3}\right)$ & 1.77 & 0.91 & 3.53 & 2.93 \\
\hline $\mathrm{POC} / \mathrm{PON} ; \mathrm{C} / \mathrm{N}(\mathrm{w} / \mathrm{w})$ & 34.6 & 32.5 & 17.1 & 19.2 \\
\hline $\mathrm{P} / \mathrm{G} / \mathrm{L}(\mathrm{w} / \mathrm{w} / \mathrm{w})$ & $0.8 / 0.3 / 1$ & $0.7 / 0.3 / 1$ & $1.2 / 0.4 / 1$ & $0.9 / 0.4 / 1$ \\
\hline \multicolumn{5}{|c|}{ Large particles $(>15 \mu \mathrm{m})$} \\
\hline $\mathrm{POC} / \mathrm{SF}\left(\mathrm{w} / \mathrm{w} \times 10^{-3}\right)$ & 0.52 & 0.55 & 1.20 & 3.44 \\
\hline $\mathrm{POC} / \mathrm{PON} ; \mathrm{C} / \mathrm{N}(\mathrm{w} / \mathrm{w})$ & 7.8 & 11.3 & 6.9 & 13.1 \\
\hline $\mathrm{P} / \mathrm{G} / \mathrm{L}(\mathrm{w} / \mathrm{w} / \mathrm{w})$ & $4.7 / 3.6 / 1$ & $2.2 / 1.3 / 1$ & $2.8 / 2.2 / 1$ & $3.3 / 2.0 / 1$ \\
\hline
\end{tabular}

summer in the St. Lawrence estuary. More recently, Levasseur et al. (1984) and Therriault \& Levasseur (1985) observed that maximum chlorophyll a values occurred in July and were followed by a drastic decrease in August. A common feature in SPM seems to be a high level of ATP measured in the smallest particle size fraction (e.g. Sutcliffe 1972, Mayzaud \& Taguchi 1979). We also found that 50 to $70 \%$ of ATP, as well as chlorophyll $a$, was contained in particles smaller than $15 \mu \mathrm{m}$ (Table 3). Flagellates, which are more abundant than diatoms in the lower St. Lawrence estuary at the end of the summer (Levasseur et al. 1984 , Therriault \& Levasseur 1985), may be responsible for these high concentrations of ATP in the small size fractions. Thus, the highest fractions of ATP (defining the living particles) and of the biochemical compounds ( $P, G, L, P O N$ : defining the nutritive value) both are contained in the smallest particles $(<15 \mu \mathrm{m})$. However, in that size category values of the $\mathrm{C} / \mathrm{N}$ ratio $(>17$, Table 4) show that the living particles are mixed with detritus which is much more abundant and, on average, less valuable as a food resource.

The silica fraction SF is used as an index of the biogenic silica or of the terngeneous alumino silicates. However, there is no clear discrimination between the origin of the particles on the basis of SF alone; this requires complementary parameters (Table 4 ). The smallest particles $(<15 \mu \mathrm{m})$ contained 66 to $92 \%$ of total SF concentration measured in seston, with the highest values being found for PSG I and II (Table 3). The concentration of SF was much less in particles larger than $15 \mu \mathrm{m}$ and decreased from PSG I to PSG IV. The POC/SF ratio was used to reflect the biogenic or terrigeneous nature of the particles (Table 4). When POC/SF $\left(\times 10^{-3}\right)>1$, we assume that particles had an organic origin and that biogenic material dominated
SPM. High POC/SF values were found both in particles $<15 \mu \mathrm{m}$ (Table 4: PSGs I, III and IV) and in particles $>15 \mu \mathrm{m}$ (Table 4: PSGs III and IV) showing that most of these particles were biogenic. Alternatively, when POC/SF $\left(\times 10^{-3}\right)<1$, as measured in PSG II for all particle size fractions and in PSG I for particles $>15 \mu \mathrm{m}$ (Table 4), we assume that the majority of these particles were inorganic and had a terrigeneous origin or were formed of diatom frustules. However, these later categories could not be differentiated on the basis of the POC/SF ratio. The discrimination between the biogenic and terrigeneous origin of particles given by the POC/SF ratios (Table 4) coincides with the pattern of the spatial distribution of the spectra in the Estuary, PSG II being mainly upstream, PSG IV being mainly downstream, whereas PSGs I and III had an intermediate distribution (Fig. 1A).

The $\mathrm{C} / \mathrm{N}$ ratio for seston varies from 2 to 35 , corresponding to the range found in living and non-living particles (Mann 1972, Eppley et al. 1977). We found a similar range in the Estuary and we use this ratio as an index of the relative amount of living particles versus detritus (Table 4). According to Russel-Hunter (1970) animals have nutritional requirements for proteins which correspond to $\mathrm{C} / \mathrm{N}$ ratios lower than 17 . At the time of sampling in the Estuary, we found that only particles $>15 \mu \mathrm{m}$ fullfilled this criterion (Table 4). The nutritive value of particles is also related to the protein/carbohydrate/lipid ratio. Parsons et al. (1961) and Scott (1980) found that for phytoplankton cultures the ratios are $4: 3: 1$ or $1: 1: 1$, in order to satisfy the food requirements of the particle filter-feeders. In nature, different values are generally found for seston (Mayzaud \& Taguchi 1979; Table 4) and only a limited stock of particles (Table 4 : particles $>15 \mu \mathrm{m}$ ) has a $\mathrm{P} / \mathrm{G} / \mathrm{L}$ ratio compatible to the food requirements defined by 
Parsons et al. (1961) and by Scott (1980). The results obtained for $\mathrm{P} / \mathrm{G} / \mathrm{L}$ and for $\mathrm{C} / \mathrm{N}$ ratios are consistent (Table 4). Thus, biogenic particles in the size fraction $>15 \mu \mathrm{m}$ could be potentially suitable to the food requirements of particle-feeders; whereas living particles in the size fraction $<15 \mu \mathrm{m}$ were too few compared to the prevailing standing stock of small size detritus which apparently did not have, on average, such a favorable food value (Tables 3 \& 4). Nevertheless, it has been shown that the combination of live and detrital diets can increase copepod production rates under specific experimental conditions, when $\mathrm{P} / \mathrm{G} / \mathrm{L}$ ratios are similar between phytoplankton and detritus (Roman 1984). This author also suggested that phytoplankton could supply essential chemical compounds (e.g. proteins, fatty acids, amino acids, vitamins) to supplement the growth demands, while detritus might provide most of the carbon and nitrogen (e.g. carbohydrates and lipids) to support the energy demands of zooplankton. Although a similar strategy may function under natural conditions, its occurrence mainly relies on the chemical composition of food (Poulet 1983, Poulet et al. 1985). For particle-feeders (e.g. oysters, Cladocera) which discriminate particles on the basis of size, the nutritive value of the particles selected is of importance. When size is not the only criterion of food selection (e.g. copepods) the uptake of the appropriate particles within a given stock of SPM is controlled by specific feeding mechanisms, such as chemosensory feeding, defined for copepods by Poulet \& Marsot (1978). Recent observations on the feeding mechanisms of copepods have shown that selectivity for food and the biochemical composition of particles determine the digestive enzyme activity and growth of zooplankton (Roman 1984, Poulet et al. 1985, Harris et al. 1986). The conclusions reached from the present results combined with those drawn by these authors indicate that among the standing stock of SPM, only particles presenting some nutritive value to the consumers are biologically important and should contribute to the transfer of organic matter into secondary production.

In summary, our results demonstrate that particles occurring in a natural environment have a distinct chemical composition relatively to both size classes and general shape of the spectra. The classification of the size spectra into various groups allowed SPM to be distinguished with respect to its nature, origin and food potential. Our multivariate approach also provides information on the characteristics of the particles and on their variations in both time and space. This approach has emphasized the efficiency of the chemical and multivariate analyses combined as tools to achieve a better understanding of the biological importance of the suspended particulate matter.
Acknowledgements. Thanks are due to the captain and crew of the CSS Dawson and M. V Jewell, to Mr. G. Canuel, M. Morissette and $\mathrm{G}$. Ouellet for technical assistance, and to $\mathrm{Mr}$ M. Juge for typing. We are grateful to Drs C. Gill, D. Vaulot. and $B$. Zeitzschel for reviewing an earlier version of the manuscript.

\section{LITERATURE CITED}

Baars, M. A., Oosterhuis, S. S. (1984). Diurnal rhythms in grazing on labelled food, gut fluorescence and digestive enzyme activities of North Sea copepods. Neth. J. Sea Res. 18: $97-119$

Bligh, E. G., Dyer, N. J. (1956). A rapid method of total lipid extraction and purification. Can. J. Biochem. Physiol. 37: 911-917

Boucher, J. A., Laurec, A., Samain, J. F., Smith, S. L. (1975). Étude de la nutrition, du régime et du rythme alimentaire du zooplancton dans les conditions naturelles, par la mesure des activités enzymatiques digestives. In: Persoone, G., Jaspers, E. (ed.) Proc. 10th European Mar. Biol. Symposium, Ostend, Belgium, Vol. 2. Universa Press, Wetteren, p. 85-110

Cauwet, G. (1978). Organic chemistry of sea water particulates. Concepts and development. Oceanologica Acta 1: 99-105

Chanut, J. P., Poulet, S. A. (1982). Short-term variability of the size spectra of suspended particles in a rapidly changing environment. Estuar. coast. Shelf Sci. 15: 497-513

Chervin, M. B., Malone, T C., Neale, P. J. (1981). Interactions between suspended organic matter and copepod grazing in the plume of the Hudson River. Estuar. coast. Shelf Sci. 13: $169-183$

Conover, R. J. (1978). Transformation of organic matter. In: Kinne, O. (ed.) Marine ecology, Vol. IV, Dynamics. J. Wiley and Sons, Chichester, p. 221-499

Conover, W. J. (1980). Practical non-parametric statistics, 2nd edn. J. Wiley \& Sons, New York

Dubois, M., Gills, K. A., Hamilton, J. K., Robers, P. A., Smith, F. (1956). Calorimetric method for determination of sugars and related substances. Analyt. Chem. 28: 350-356

Eppley, R. W., Harrisson, W. G., Chisholm, S. W., Stewart, E. (1977). Particulate organic matter in surface waters off southern California and its relationship to phytoplankton. J. mar. Res. 35: 671-696

Gordon, D. C., Wangersky, P. J., Sheldon, R. W. (1979). Detailed observations on the distribution and composition of particulate organic material at two stations in the Sargasso sea. Deep Sea Res. 26A: 1083-1092

Harris, R. P., Moal, J., Samain, J. F., Martin-Jezequel, V., Poulet, S. A. (1986). Effects of algal diet on digestive enzyme activity in Calanus helgolandicus. Mar. Biol. 90: $279-284$

Hitchock, G. L. (1982). A comparative study of the sizedependent organic composition of marine diatoms and dinoflagellates. J. Plankton Res. 4: 363-377

Holm-Hansen, O., Booth, C. (1966). The measurements of adenosine triphosphate in the ocean and its ecological significance. Limnol. Oceanogr. 11: 510-519

Huntley, M. E. (1982). Yellow water in La Jolla Bay, California, July 1980. II. Suppression of zooplankton grazing. J. exp. mar. Biol. Ecol. 63: 81-92

Jørgensen, C. B. (1966). Biology of suspension feeding. Pergamon Press, London 
Jullien, D., Cauwet, G., Marty, J. C., Saliot, A. (1982). La matière organique dans la microcouche de surface des eaux de mer: bilan, accumulation et complexation. C. r. hebd. Séanc. Acad. Sci., Paris, Série II. 295: 367-370

Klecka, W. R. (1975). Discriminant analysis. In: Statistical package for the social sciences. 2nd edn. Mc Graw-Hill, New York, p. 434-467

Lachenbruch, P. A. (1977). Some misuses of discriminant analysis. Meth. infor. Med. 16: 255-258

Levasseur, M., Therriault, J.-C., Legendre, L. (1983). Tidal currents, winds and the morphology of phytoplankton spatial structures. J. mar. Res. 41:655-671

Levasseur, M., Therriault, J.-C., Legendre, L. (1984). Hierarchical control of phytoplankton succession by physical factors. Mar. Ecol. Prog. Ser 19: 211-222

Lowry, O. H., Rosebrough, N. J., Farr, A. L., Randall, R. J. (1951). Protein measurement with Folin Phenol reagent. J biol. Chem. 193: 265-275

Malone, T. C., Chervin, M. B. (1979). The production and fate of phytoplankton size fractions in the plume of the Hudson River, New York Bight. Limnol. Oceanogr. 24: 683-696

Malone, T. C., Chervin, M. B., Boardman, D. C. (1979). Effects of $22 \mu \mathrm{m}$ screens on size frequency distributions of suspended particles and biomass estimates of phytoplankton size fractions. Limnol. Oceanogr. 24: 956-960

Mann, K. H. (1972). Macrophyte production and detritus food chain in coastal waters. In: Melchiori-Santolini, U., Hopton, J. W. (ed.) Detritus and its role in aquatic ecosystems, Vol. 29 (suppl.) Memorie Ist. ital. Idrobiol., 258-384

Mayzaud, P., Poulet, S. A. (1978). The importance of the time factor in the response of zooplankton to varying concentrations of naturally occurring particulate matter. Limnol. Oceanogr, 23: 1144-1154

Mayzaud, P., Taguchi, S. (1979). Size spectral and biochemical characteristics of the particulate matter in the Bedford Basin. J. Fish. Res. Bd Can. 36: 211-218

Mayzaud, P., Taguchi, S., Laval, Ph. (1984). Seasonal patterns of seston characteristics in Bedford Basin, Nova Scotia, relative to zooplankton feeding: A multivariate approach. Limnol. Oceanogr. 29: 745-762

Mullin, M. M. (1965). Size fractionation of particulate organic carbon in the surface waters of the western Indian Ocean. Limnol. Oceanogr. 10: 459-462

Nie, N. H., Hull, C. H., Jenkins, J. G., Steinbrenner, K., Bent, D. H. (1975). Principal component analysis. In: Statistical package for the social sciences, 2nd edn. Mc Graw-Hill, New York

Parsons, T. R. (1969). The use of particle size spectra in determining the structure of the plankton community. $\mathrm{J}$. oceanogr. Soc. Japan 25: 6-15

Parsons, T. R., Stephens, K., Strickland, J. D. H. (1961). On the chemical composition of eleven species of marine phytoplankton. J. Fish. Res. Bd Can. 18: 1001-1016

Poulet, S. A., Marsot, P. (1978). Chemosensory grazing by marine calanoid copepods (Arthropoda: Crustacea). Science 200: 1403-1405

Poulet, S. A. (1983). Factors controlling utilization of non algal diets by particle-grazing copepods. A review. Oceanologica Acta 6: 221-234

Poulet, S. A., Samain, J. F., Moal, J. (1985). Chemoreception, nutrition and food requirements among copepods. In: Proc. Second International Conference on Copepoda. Ottawa, Canada, 13-17 August, 1984. (In Press)

Poulet, S. A., Chanut, J. P., Morissette, M. (1986). Étude du spectre de taille des particules en suspension dans l'estuaire et le Golfe du Saint-Laurent. I. Variations spatiales. Oceanologica Acta 9: in press

Postma, H. (1967). Sediment transport and sedimentation in the estuarine environment. In: Lauff, G. (ed.) Estuaries. AAAS Publ. No. 83: 158-179

Riley, G. A. (1970). Particulate organic matter in sea water, Adv. mar. Biol. 8: 1-118

Roman, M. R. (1984). Utilization of detritus by the copepod, Acartia tonsa. Limnol. Oceanogr. 29: 949-959

Russel-Hunter, W. D. (1970). Aquatic productivity: an introduction to some basic aspects of biological oceanography and limnology. Collier-MacMillan, London

Schubel, J. R. (1971). Tidal variation of the size distribution of suspended sediment at a station in the Chesapeake Bay turbidity maximum. Neth. J. Sea Res. 5: 252-266

Scott, J. M. (1980). Effect of growth rate of the food alga in the growth/ingestion efficiency of a marine herbivore. J. mar. biol. Ass. U.K. 60: 681-702

Sheldon, R. W. Parsons, T R. (1967). A continuous size spectrum for particulate matter in the sea. J. Fish. Res. Bd Can. 24: 909-915

Sheldon, R. W., Prakash, A., Sutcliffe, W. H. (1972). The size distribution of particles in the Ocean. Limnol. Oceanogr $17: 327-340$

Sinclair, M. Chanut, J. P., El-Sabh, M. (1980). Phytoplankton distributions observed during a $3 \frac{1}{2}$ days fixed station in the lower St. Lawrence Estuary. Hydrobiologia 75: 129-147

Strathmann, R. R. (1967). Estimating the organic carbon content of phytoplankton from cell volume or plasma volume Limnol. Oceanogr. 12: 411-418

Strickland, J. D., Parsons, T R. (1967). A practical handbook of seawater analysis. Bull. Fish. Res. Bd Can. 167

Sutcliffe, W H. (1972). Some relations of land drainage, nutrients, particulate material and fish catch in two eastern Canadian bays. J. Fish. Res Bd Can. 29: 357-362

Therriault, J. C., Levasseur, M. (1985). Control of phytoplankton production in the lower St. Lawrence estuary: light and freshwater runoff. Naturaliste can. 112: 77-96

Valkenberg, S. D. Van, Jones, J. K., Heinle, D. R. (1978). A comparison by size class and volume of detritus versus phytoplankton in Chesapeake Bay. Estuar. coast. mar. Sc1. 6: 569-582 